\title{
The Small G Protein H-Ras in the Mesolimbic System Is a Molecular Gateway to Alcohol-Seeking and Excessive Drinking Behaviors
}

\author{
Sami Ben Hamida, ${ }^{1 *}$ Jeremie Neasta, ${ }^{1 \star}$ Amy W. Lasek, ${ }^{1}$ Viktor Kharazia, ${ }^{1}$ Mimi Zou, ${ }^{1}$ Sebastien Carnicella, ${ }^{1,2}$ \\ Patricia H. Janak, ${ }^{1,2}$ and Dorit Ron ${ }^{1,2}$ \\ ${ }^{1}$ Ernest Gallo Research Center and ${ }^{2}$ Department of Neurology, University of California, San Francisco, Emeryville, California 94608
}

Uncontrolled consumption of alcohol is a hallmark of alcohol abuse disorders; however, the central molecular mechanisms underlying excessive alcohol consumption are still unclear. Here, we report that the GTP binding protein, H-Ras in the nucleus accumbens (NAc) plays a key role in neuroadaptations that underlie excessive alcohol-drinking behaviors. Specifically, acute (15 min) systemic administration of alcohol $(2.5 \mathrm{~g} / \mathrm{kg})$ leads to the activation of H-Ras in the NAc of mice, which is observed even $24 \mathrm{~h}$ later. Similarly, rat operant self-administration of alcohol (20\%) also results in the activation of H-Ras in the NAc. Using the same procedures, we provide evidence suggesting that the exchange factor GRF1 is upstream of H-Ras activation by alcohol. Importantly, we show that infection of mice NAc with lentivirus expressing a short hairpin RNA that targets the $\mathrm{H}$-Ras gene produces a significant reduction of voluntary consumption of $20 \%$ alcohol. In contrast, knockdown of H-Ras in the NAc of mice did not alter water, quinine, and saccharin intake. Furthermore, using two-bottle choice and operant self-administration procedures, we show that inhibiting H-Ras activity by intra-NAc infusion of the farnesyltransferase inhibitor, FTI-276, produced a robust decrease of rats' alcohol drinking; however, sucrose consumption was unaltered. Finally, intra-NAc infusion of FTI-276 also resulted in an attenuation of seeking for alcohol. Together, these results position H-Ras as a central molecular mediator of alcohol's actions within the mesolimbic system and put forward the potential value of the enzyme as a novel target to treat alcohol use disorders.

\section{Introduction}

The small GTPase H-Ras belongs to the p21 family of Ras proteins that transduce extracellular signals by cycling between an inactive GDP-bound state and an active GTP-bound state (Takai et al., 2001; Cox and Der, 2010). H-Ras is the most abundant p21Ras isoform expressed in the adult brain (Leon et al., 1987), and its transcript is distributed throughout the brain including the striatum (Manabe et al., 2000). H-Ras activity in the CNS is tightly controlled by the exchange factor guanine nucleotidereleasing factor 1 (GRF1), which promotes the dissociation of GDP from H-Ras and its replacement by GTP (Feig, 2011; Fernández-Medarde and Santos, 2011). Conversely, GTPaseactivating proteins such as neurofibromin protein type 1 (NF1)

Received June 14, 2012; revised Aug. 17, 2012; accepted Sept. 15, 2012.

Author contributions: S.B.H., J.N., S.C., P.H.J., and D.R. designed research; S.B.H., J.N., A.W.L., V.K., and M.Z performed research; S.B.H. and J.N. analyzed data; S.B.H., J.N., and D.R. wrote the paper.

This work was supported by National Institutes of Health-National Institute on Alcohol Abuse and Alcoholism P50 AA017072 (D.R.), and the State of California for Medical Research on Alcohol and Substance Abuse through the University of California, San Francisco (D.R. and P.H.J.).We thank Jana Lim and Quinn Yowell for technical assistance and Drs. Segev Barak and Woody Hopf for carefully reviewing this manuscript.

* S.B.H. and J.N. contributed equally to this work.

The authors declare no competing financial interests.

Correspondence should be addressed to Dr. Dorit Ron, University of California, 5858 Horton Street, Suite 200, Emeryville, CA 94608. E-mail: dron@gallo.ucsf.edu.

S. Carnicella's present address: Grenoble Institute of Neuroscience, INSERM U836, Team 10, 38706, La Tronche, France.

DOI:10.1523/JNEUROSCI.2846-12.2012

Copyright $\odot 2012$ the authors $\quad 0270-6474 / 12 / 3215849-10 \$ 15.00 / 0$ stimulate the intrinsic GTPase activity of H-Ras leading to the recycling of the enzyme to its inactive form (Bos et al., 2007). p21Ras proteins are synthesized as cytoplasmic precursors and require post-translational lipid modifications, namely farnesylation of the C-terminal cysteine residue, to be anchored to the plasma membrane and to acquire full biological activity (Zhang and Casey, 1996; Ahearn et al., 2012). Like other members of the p21Ras family, once activated, H-Ras stimulates downstream signaling cascades including the phosphatidylinositol-3-kinase $(\mathrm{PI} 3 \mathrm{~K}) /$ protein kinase B (AKT) and the mitogen-activated protein kinase (MAPK) pathways (Moodie et al., 1993; Orban et al., 1999; Castellano and Downward, 2011).

In the CNS, Ras proteins play a role in cellular mechanisms underlying synaptic plasticity and memory formation via both presynaptic and postsynaptic mechanisms (Ye and Carew, 2010). Inhibition of Ras signaling results in abnormal cellular plasticity and subsequent deficiencies in learning and memory such as amygdala-dependent memory consolidation (Brambilla et al., 1997; Kim et al., 2003). Specifically for H-Ras, the enzyme contributes to the inhibition of Src phosphorylation of the NR2A subunit of the $N$-methyl-D-aspartate receptor (NMDAR) and to the inhibition of synaptic membranal retention of the subunit (Thornton et al., 2003). Transgenic mice expressing a constitutively active form of the enzyme (H-RasG12V) exhibit increased hippocampal learning and memory (Kushner et al., 2005) and increased plasticity in the developing visual cortex (Kaneko et al., 2010), as well as alterations in neuronal morphology (Alpár et al., 
2004; Gärtner et al., 2004). Furthermore, consistent with the role of H-Ras in promoting long-term plasticity, GRF1 and NF1 transgenic mice also exhibit alterations in memory formation (Costa et al., 2002; Ye and Carew, 2010). Therefore, H-Ras appears to be a mediator of signaling events that endurably impact synaptic plasticity.

Uncontrolled drug and alcohol intake are thought to stem, at least in part, from aberrant synaptic plasticity processes within the mesolimbic system including the nucleus accumbens (NAc, Hyman et al., 2006; Russo et al., 2010). Rodent procedures that model excessive and binge-like drinking behaviors in humans enable the identification of mechanisms underlying excessive uncontrolled alcohol seeking and drinking (Sprow and Thiele, 2012). Specifically, recurring cycles of alcohol intake and withdrawal drive excessive consumption and binge drinking in humans (Koob, 2003; Vengeliene et al., 2008; Koob and Volkow, 2010). These phenotypes have been successfully mimicked in mice and rats undergoing sessions of voluntary intake of $20 \%$ alcohol and withdrawal (Simms et al., 2008; Carnicella et al., 2009; Neasta et al., 2010; Barak et al., 2011). These procedures lead to the consumption of large quantities of alcohol over a short period of time ( $4 \mathrm{~h}$ in mice, $30 \mathrm{~min}$ in rats) that result in a blood alcohol concentration of $>80 \mathrm{mg} \%$, which corresponds to human binge drinking as defined by the National Institute on Alcohol Abuse and Alcoholism (Carnicella et al., 2009; Neasta et al., 2010). The use of these paradigms allowed us to test the hypothesis that H-Ras in the NAc is necessary for mechanisms that underlie excessive alcohol drinking behaviors.

\section{Materials and Methods Materials}

Anti-H-Ras antibody, Ras activity assay reagent (glutathione $S$-transferase fused to the Ras binding domain of Raf- 1 bound to agarose, Raf-1 RBD), anti-NeuN antibody, and nitrocellulose membrane were purchased from Millipore. Anti-phospho-GRF1 Ser ${ }^{916}$ antibody was purchased from Cell Signaling Technology. Anti-GRF1 (sc-224) antibody and horseradish peroxidase (HRP)-conjugated secondary antibodies were purchased from Santa Cruz Biotechnology. EDTA-free complete mini Protease Inhibitor Cocktail was purchased from Roche, and the phosphatase inhibitor cocktails 1 and 2, antiglial fibrillary acidic protein (GFAP), and paraformaldehyde (PFA) were purchased from Sigma Aldrich. The farnesyl transferase inhibitor FTI-276 was purchased from Calbiochem. NuPAGE Bis-Tris precast gels and Trizol reagent were purchased from Invitrogen. Enhanced Chemiluminescence (ECL) plus was purchased from GE Healthcare and BioMax MR Film was purchased from Kodak. The p24 antigen ELISA kit was purchased from Zeptometrix. Euthasol was purchased from Virbac. Anti-green fluorescent protein (GFP) antibody was purchased from Abcam. Alexa Fluor 488-labeled donkey anti-rabbit and Alexa Fluor 594-labeled donkey anti-mouse were purchased from Invitrogen. Vectashield mounting medium was purchased from Vector Laboratories.

\section{Animals}

Male Long-Evans rats (Harlan; 400-450 g at the time of surgery, 4-5 months old) and male C57BL/6J mice (The Jackson Laboratory; 25-30 g at the time of surgery; 3 months old) were individually housed in a temperature- and humidity-controlled room under a $12 \mathrm{~h}$ light/dark cycle, with food and water available ad libitum. All animal procedures in this report were approved by the Gallo Center Institutional Animal Care and Use Committee and were conducted in agreement with the Guide for the Care and Use of Laboratory Animals, National Research Council, 1996.

\section{Drugs and treatments}

Alcohol solutions for the drinking experiments were prepared from absolute anhydrous alcohol (190 proof) diluted to $20 \%$ alcohol (v/v) in tap water. For systemic administration, alcohol was diluted to $20 \%$ alcohol (v/v) in saline. FTI-276 was dissolved in 10\% dimethylsulfoxide (DMSO) in PBS.

\section{Collection of brain samples for biochemical analyses}

Experiments in mice. To measure the effect of systemic alcohol administration on H-Ras activity and GRF1 phosphorylation, mice were killed 15 min after a single administration of alcohol. This experiment was conducted three times using separate groups of animals.

To test the effect of Ltv-shH-Ras1 or Ltv-shH-Ras2 on the level of $\mathrm{H}$-Ras, mice were killed 8 weeks after virus infusion by cervical dislocation; brains were quickly removed and placed on an ice-cold platform.

Experiments in rats. At the end of the $30 \mathrm{~min}$ self-administration session, animals were anesthetized by isoflurane, killed by decapitation, and brains were quickly removed and placed on an ice-cold platform and the level of H-Ras activity and GRF1 phosphorylation were measured. The experiment was conducted twice using separate groups of animals.

The NAc of mice or rats was dissected and immediately homogenized in magnesium lysis buffer (MLB) supplemented with protease and phosphatase inhibitors (for H-Ras activity assay and phospho-GRF1 analysis) or in radioimmunoprecipitation assay buffer containing $25 \mathrm{~mm}$ Tris$\mathrm{HCl}, \mathrm{pH}$ 7.6, $150 \mathrm{~mm} \mathrm{NaCl}$, EDTA 1 mм, 1\% (v/v) NP-40, 0.5\% (w/v) sodium deoxycholate, and $0.1 \%(\mathrm{w} / \mathrm{v})$ SDS supplemented with protease inhibitors (for H-Ras knockdown analysis).

\section{Measurement of H-Ras activity}

Five hundred micrograms of homogenates at a concentration of $1 \mu \mathrm{g} / \mu \mathrm{l}$ in MLB were precleared for 30 min with GST-agarose beads and then incubated with $30 \mu$ l of Raf- 1 binding domain (RBD) agarose for 40 min at $4^{\circ} \mathrm{C}$. Agarose beads were washed three times with $1 \mathrm{ml}$ of MLB. Bound proteins were eluted with loading buffer, boiled for $10 \mathrm{~min}$, and resolved by SDSPAGE. GTP bound H-Ras immunoreactivity was detected by Western blot analysis using anti H-Ras antibody.

\section{Western blot analysis}

Proteins were resolved by SDS-PAGE and then transferred to a nitrocellulose membrane. Membranes were blocked for $1 \mathrm{~h}$ with $5 \%(\mathrm{w} / \mathrm{v})$ nonfat milk in Tris buffer saline $0.1 \%(\mathrm{v} / \mathrm{v})$, Tween 20 , and then incubated overnight at $4^{\circ} \mathrm{C}$ with the appropriate antibody. Bound primary antibodies were detected with HRP-conjugated secondary antibody and visualized by ECL plus. The optical density of the relevant immunoreactive band was quantified using National Institutes of Health ImageJ 1.63 program.

\section{Production of lentivirus expressing shRNA targeting H-Ras}

The 19-nucleotide short hairpin RNA (shRNA) sequence targeting H-Ras (Ltv-shH-Ras1) 5'-GUA CAG GGA GCA GAU CAA G was chosen based on a previous study (Mor et al., 2008). A second sequence, Ltv-shH-Ras2, 5' -GGA CCU UGC UCG CAG CUA U, was designed using the Thermo Scientific siDesign Center (http://www. dharmacon.com/designcenter/designcenterpage.aspx). The sequences were incorporated into a previously described stem-loop structure (Rubinson et al., 2003). Synthesized oligonucleotides were annealed and subcloned into the $\mathrm{HpaI}$ and XhoI restriction sites in the recombinant lentiviral vector pLL3.7, which also expresses enhanced GFP (EGFP). The production of recombinant lentivirus was conducted as described previously (Lasek et al., 2007). The nonrelated 19 nucleotide sequence 5'-GCG CUU AGC UGU AGG AUU (Ltv-NS), which has no significant identity to any mouse or rat mRNA, was cloned as previously described (Lasek et al., 2007) and was used as a nontargeting control shRNA. The scrambled sequence of Ltv-shHRas1 (Ltv-SCR), 5'-GGG AAG UCC AUG CGA AGU A, was also used as a control. Lentiviruses were concentrated by centrifugation and titers were determined using the p24 antigen ELISA as described previously (Lasek et al., 2007). Viral titer for in vivo administration was $4 \times 10^{7} \mathrm{pg} / \mathrm{ml}$. 


\section{Immunochemistry}

At the end of behavioral experiments, mice were deeply anesthetized with Euthasol and perfused with $0.9 \% \mathrm{NaCl}$, followed by $4 \%$ PFA in phosphate buffer, $\mathrm{pH}$ 7.4. Brains were removed, fixed in the same fixative for $2 \mathrm{~h}$, and transferred to PBS at $4^{\circ} \mathrm{C}$. The following day, brains were transferred into $30 \%$ sucrose and stored for $3 \mathrm{~d}$ at $4^{\circ} \mathrm{C}$. Frozen $50-\mu \mathrm{m}$-thick coronal sections were cut on a cryostat (Microm; ThermoFisher Scientific) and collected into 24 -well dishes. Free-floating sections containing the injection site in the striatum were selected, and first permeabilized with 50\% alcohol for $10 \mathrm{~min}$, then rinsed in PBS. Sections were then blocked with $10 \%$ normal donkey serum in PBS for $30 \mathrm{~min}$ and incubated for $48 \mathrm{~h}$ at $4^{\circ} \mathrm{C}$ on an orbital shaker with antibodies for either neuronal marker (anti-NeuN antibody) or glial marker (anti-GFAP antibody) in combination with anti-GFP antibody, diluted in PBS/ $0.05 \%$ Triton X-100. Next, sections were washed in PBS, incubated with $2 \%$ normal donkey serum for $10 \mathrm{~min}$, and incubated for $4 \mathrm{~h}$ with secondary antibodies: Alexa Fluor 488-labeled donkey anti-rabbit and Alexa Fluor 594-labeled donkey anti-mouse. After staining, sections were rinsed in PBS and coverslipped using Vectashield mounting medium. Images were acquired using a Zeiss LSM 510 META laser confocal microscope (Zeiss MicroImaging) according to factoryrecommended filter configurations.

\section{Mouse experiments}

\section{Systemic administration of alcohol}

Mice were habituated to the injection procedure by daily intraperitoneal administration of saline for 3 consecutive days. On day 4, alcohol (2.5 $\mathrm{g} / \mathrm{kg}, 20 \%(\mathrm{v} / \mathrm{v})$ ) or saline was administered in a volume of $15.6 \mathrm{ml} / \mathrm{kg}$ and brain samples were collected as described above.

\section{Infusion of virus}

Mice were anesthetized using a mixture of ketamine $(120 \mathrm{mg} / \mathrm{kg})$ and xylazine ( $8 \mathrm{mg} / \mathrm{kg}$ ). The injector (stainless tubing, 33 gauge; Small Parts) was stereotaxically positioned in the NAc (bregma coordinates, anteroposterior $+1.7 \mathrm{~mm}$; lateral $\pm 0.65 \mathrm{~mm}$; dorsoventral $-4.4 \mathrm{~mm})$. The injectors were connected to Hamilton syringes ( $10 \mu \mathrm{l}$; 1701; Harvard Apparatus), and the infusion was controlled by an automatic pump (Harvard Apparatus). Mice were infused with $1 \mu \mathrm{l}$ of lentivirus (LtvshH-Ras1, Ltv-shH-Ras2, Ltv-SCR, or Ltv-NS $)\left(4 \times 10^{7} \mathrm{pg} / \mathrm{ml}\right)$ at an injection rate of $0.1 \mu \mathrm{l} / \mathrm{min}$. Mice recovered for 4 weeks in their home cages before experiments were initiated. Only data from subjects with infection localized in the NAc were included in the analysis.

\section{Continuous access, 20\% alcohol two-bottle choice} drinking paradigm

Ltv-shH-Ras1, Ltv-NS, Ltv-shH-Ras2, or Ltv-SCR was infused into the NAc of mice. Four weeks later, oral alcohol intake was determined using continuous access to $20 \%$ alcohol in a two-bottle choice drinking paradigm. This procedure is based on a paradigm described previously (McGough et al., 2004). Briefly, mice had access to two bottles, one containing a $20 \%$ alcohol solution (v/v) and the other containing tap water, for 2 weeks. Drinking sessions were conducted $24 \mathrm{~h}$ a day, $7 \mathrm{~d}$ a week. The bottles were weighed every day at 12:00 P.M. and the mice were weighed once a week. The position (left or right) of each solution was alternated every day to control for side preference.

\section{Quinine and saccharin taste test}

One week after the end of the alcohol-drinking study, mice were tested for quinine and saccharin intake. The procedure was similar to the continuous access alcohol two-bottle choice drinking paradigm described above, except that alcohol was substituted for a saccharin $(0.066 \%)$ or quinine hemisulfate $(0.06 \mathrm{~mm})$ solution. Each solution was offered for $3 \mathrm{~d}$ and the amount of fluid intake was recorded every day.

\section{Intermittent limited-access $20 \%$ alcohol drinking paradigm}

Ltv-shH-Ras1 or Ltv-SCR ( $1 \mu \mathrm{l} / \mathrm{side})$ was infused into the NAc of mice. Four weeks later, oral alcohol intake was determined using an intermittent limited-access $20 \%$ alcohol drinking paradigm as previously described (Neasta et al., 2010). Briefly, mice had access to a $20 \%$ alcohol solution (v/v) for $4 \mathrm{~h}$ every other day for 2 weeks. A water bottle was always available except during the $4 \mathrm{~h}$ alcohol access sessions.

\section{Rat experiments}

\section{Cannulae implantation and microinfusion procedure}

Rats were continuously anesthetized with isoflurane (Baxter) during the surgery for placement of the bilateral guide cannulae (C235G, 26 ga; Plastics One). The stereotaxic coordinates for the NAc were $+1.6 \mathrm{~mm}$ anterior to bregma, $\pm 1 \mathrm{~mm}$ lateral to the medial suture, and $-6.1 \mathrm{~mm}$ from the skull surface. Bilateral intracerebral microinfusions were made through stainless steel injectors extended $1 \mathrm{~mm}$ below the tip of the cannula. Animals were infused with FTI-276 (10 or $100 \mathrm{ng} / \mathrm{side} ; 1 \mu \mathrm{l} / 2.5$ $\min$ ) or vehicle $3 \mathrm{~h}$ before the beginning of the $24 \mathrm{~h}$ alcohol drinking or operant self-administration session. After infusion, animals were returned to the home cage until the testing session.

\section{Intermittent-access $20 \%$ alcohol two-bottle choice drinking paradigm}

The intermittent-access to $20 \%$ alcohol two-bottle choice drinking procedure was conducted as described previously (Carnicella et al., 2009). Briefly, rats were given $24 \mathrm{~h}$ of concurrent access to one bottle of $20 \%$ alcohol (v/v) in tap water and one bottle of water. The drinking session started at 12:00 P.M. on Monday, Wednesday, and Friday, with 24 or $48 \mathrm{~h}$ (weekend) alcohol-deprivation periods between the alcohol-drinking sessions. The placement (left or right) of each solution was alternated between each session to control for side preference. The water and alcohol bottles were weighed $30 \mathrm{~min}$ and $24 \mathrm{~h}$ after the beginning of the session. To assess the effect of intra-NAc infusion of FTI-276 on alcohol intake, cannulae were implanted into the NAc as described above. After $4 \mathrm{~d}$ of recovery, the two-bottle choice drinking procedure was resumed.

\section{Operant alcohol self-administration paradigm}

The operant self-administration paradigm was performed as previously described (Neasta et al., 2010). Rats were first habituated to drink alcohol in their home cage using the intermittent-access to $20 \%$ alcohol two-bottle choice drinking procedure as described above. The self-administration chambers contain two levers: an active lever, for which the presses result in delivery of $0.1 \mathrm{ml}$ of a $20 \%$ alcohol solution, and an inactive lever, for which responses are counted but no programmed events occur. After $4 \mathrm{~d}$ under a fixed ratio 1 (FR1) (one response delivers one reward), rats were trained on an FR3 schedule (three responses deliver one reward) $5 \mathrm{~d}$ a week in 30 min sessions. Animals were trained for 5 weeks before experimental manipulation. During the self-administration sessions, several parameters such as number of presses on the active and inactive lever, number of alcohol deliveries, latency to the first reward, time delay between two successive presses, and latency to the last press were recorded using MED-PC IV software (Med Associates). To assess the effect of intra-NAc infusion of FTI-276 on alcohol self-administration, cannulae were implanted into the NAc as described above. After $4 \mathrm{~d}$ of recovery, the operant selfadministration procedure was performed as described above. All subjects received vehicle or FTI-276 (100 ng/side) in a counterbalanced manner, with one microinfusion per week.

\section{Sucrose self-administration}

Rats were initially trained under FR1 using $8 \%$ sucrose during two overnight sessions. Next, the FR schedule was increased to FR3 and the sucrose concentration was progressively decreased to $1.5 \%$. Rats were tested $5 \mathrm{~d}$ a week, for 4 weeks, in 30 min sessions. Guide cannulae implantation into the NAc and the microinjection procedure were performed as described above. All subjects received both treatments in a counterbalanced manner, with one microinfusion per week.

\section{Histology}

Rats implanted with cannulae received an intraperitoneal injection of pentobarbital followed by transcardial perfusion with $4 \%$ PFA. Locations of cannulae were verified in $50 \mu \mathrm{m}$ coronal sections stained with thionin to allow visualization of probe tracks in the NAc. Only subjects with cannulae located within the NAc were included in the study. 


\section{Statistical analysis}

Biochemical data were analyzed by unpaired $t$ test. Correlations were analyzed by linear regression. Rat operant self-administration experiments were conducted in a within-subject design, whereas rat two-bottle choice and mouse experiments were conducted in a between-subject design. Depending on the experiment, data were analyzed with one-way or two-way ANOVA with or without repeated measures. Significant main effects and interactions revealed by ANOVA analyses were further investigated with the Student-Newman-Keuls post hoc test or the method of contrasts. Statistical significance was set at $p<0.05$.

\section{Results}

Alcohol activates H-Ras in the NAc of rodents

To test whether in vivo exposure to alcohol alters the activity of $\mathrm{H}$-Ras in the NAc, C57BL/6J mice were systemically treated intraperitoneally with a single nonhypnotic dose of alcohol (2.5 $\mathrm{g} / \mathrm{kg}$ ) and the level of H-Ras in its GTP-bound (thus active) form was measured. As shown in Figure $1 A$, acute in vivo exposure of mice to alcohol results in a robust activation of $\mathrm{H}$-Ras in the NAc $\left(t_{(16)}=2.93, p<0.01\right)$. To determine whether alcohol-mediated activation of $\mathrm{H}$-Ras is long-lasting, mice were treated as described above and the level of GTP-bound H-Ras was measured $24 \mathrm{~h}$ later. As shown in Figure 1B, acute in vivo exposure of mice to alcohol results in a prolonged activation of H-Ras in the NAc $\left(t_{(10)}=3.26\right.$, $p<0.01)$. Next, we tested whether alcohol self-administration produces similar changes in the activity of the enzyme. To do so, rats underwent an intermittent-access $20 \%$ alcohol two-bottle choice drinking procedure for 4 weeks, and were then trained to orally self-administer a solution of $20 \%$ alcohol in an operant procedure for 5 weeks. Control rats underwent the same procedures but consumed only water throughout the experiment and were exposed to the operant chamber for an equal period of time. H-Ras activity in the NAc was examined immediately after the last operant selfadministration session. As depicted in Figure $1 C$, the level of GTP-bound, active H-Ras was significantly increased in the NAc of rats that were lever pressing ad libitum for a high concentration of alcohol (20\%), compared with rats that were never exposed to alcohol $\left(t_{(6)}=3.05, p=0.02\right)$. Together, these results suggest that self-administered as well as experimenter-administered alcohol activates $\mathrm{H}$-Ras in the NAc.

\section{Alcohol increases GRF1 phosphorylation in the NAc of rodents}

Next, we examined a possible mechanism for alcohol-mediated activation of H-Ras. The enhancer of H-Ras activity, GRF1, is a substrate of protein kinase A (PKA) (Baouz et al., 2001), and PKA-mediated phosphorylation of GRF1 enhances the activity of the exchange factor (Mattingly, 1999; Yang et al., 2003). The cAMP/PKA pathway is one of the major signaling cascades activated in the brain in response to alcohol (Mailliard and Diamond, 2004; Ron and Messing, 2013). Thus, we tested the possibility that GRF1 phosphorylation in the NAc is increased in response to alcohol exposure. As illustrated in Figure $2 A$, systemic administration of alcohol $(2.5 \mathrm{~g} / \mathrm{kg})$ enhanced the phosphorylation of GRF1 on the PKA phosphorylation site Ser ${ }^{916}$ $\left(t_{(16)}=3.6, p=0.002\right)$. Furthermore, a positive correlation between the levels of H-Ras bound to GTP and phospho-Ser ${ }^{916} \mathrm{GRF} 1$ was observed in the NAc of mice treated with alcohol but not in mice treated with saline (Fig. 2B). Importantly, rat operant selfadministration of $20 \%$ alcohol also increased phosphorylation of GRF1 in the NAc compared with control rats (Fig. $2 C$; $t_{(6)}=1.96$, $p=0.049)$. Neither alcohol exposure paradigms produced a change in the total levels of H-Ras or GRF1. Together, these data suggest that systemic and voluntary administration of alcohol
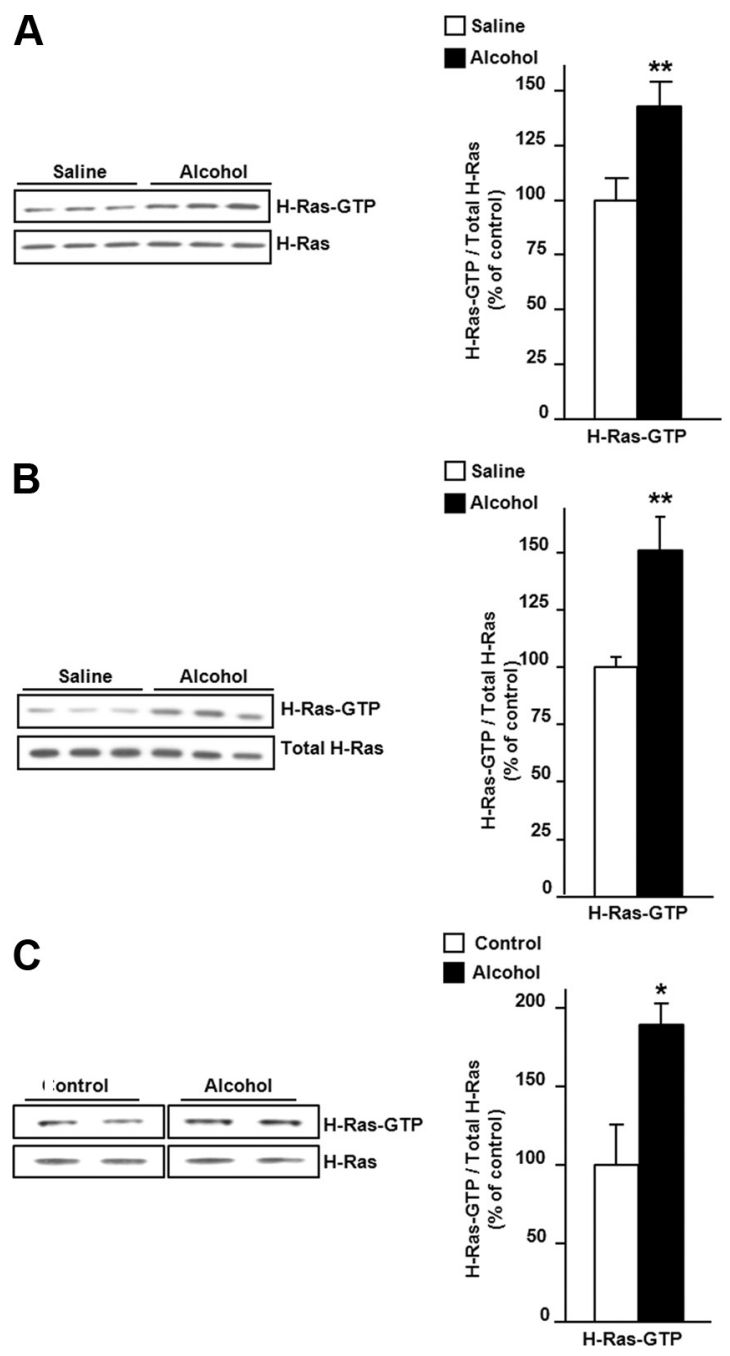

Figure 1. Systemic and self-administration of alcohol increases H-Ras activity in the NAc of rodents. $\boldsymbol{A}, \boldsymbol{B}$, Mice were systemically treated with alcohol $(2.5 \mathrm{~g} / \mathrm{kg}$, i.p.) or saline, and the NAC was removed $15 \mathrm{~min}(\boldsymbol{A})$ or $24 \mathrm{~h}(\boldsymbol{B})$ later. $\boldsymbol{C}$, The NAc of rats lever pressing for $20 \%$ alcohol and control rats that were never exposed to alcohol were collected at the end of the last $30 \mathrm{~min}$ operant session. Active GTP-bound H-Ras was isolated by a pull-down assay using Raf-1 RBD agarose beads. The levels of H-Ras-GTP and total H-Ras were determined by Western blot analysis. Optical density quantification of $\mathrm{H}$-Ras is expressed as the ratio of $\mathrm{H}$-Ras-GTP to the total H-Ras protein. Data are presented as mean \pm SEM, and expressed as percentage of control. Two-tailed unpaired $t$ test, ${ }^{*} p<0.05,{ }^{* *} p<0.01 ; n=9(\boldsymbol{A}), n=6(\boldsymbol{B})$, and $n=4(\boldsymbol{C})$ per group.

lead to the phosphorylation of GRF1, thus enhancing the activity of the exchange factor which, in turn, enables the activation of $\mathrm{H}-\mathrm{R}$ as in the NAc.

\section{Knockdown of H-Ras in the NAc of mice}

To identify the functional consequences of H-Ras activation in the NAc in response to alcohol, we generated lentiviruses expressing EGFP and one of two distinct shRNA sequences targeting $\mathrm{H}$-Ras (Ltv-shH-Ras1 and Ltv-shH-Ras2) as well as viruses expressing a nonspecific sequence (Ltv-NS) and a scrambled sequence of shH-Ras1 (Ltv-SCR). Infusion of Ltv-shH-Ras1 or Ltv-shH-Ras2 into the NAc of mice resulted in a high level of infection exclusively in neurons (Fig. 3A, Ltv-shH-Ras 1 and data not shown, Ltv-shH-Ras2). Importantly, the level of H-Ras protein was significantly reduced in the NAc of mice infected with Ltv-shH-Ras1 $\left(t_{(13)}=3.19, p=0.007\right)$ or Ltv-shH-Ras2 $\left(t_{(12)}=\right.$ 

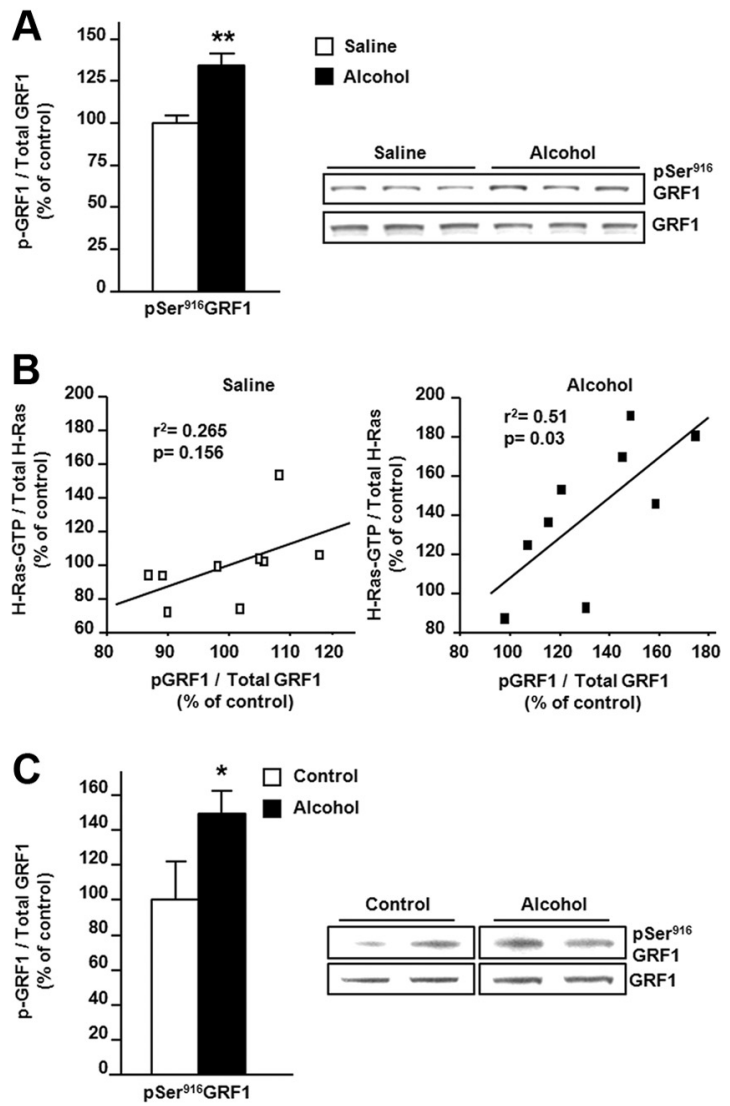

Figure 2. Systemic and self-administration of alcohol increase GRF1 phosphorylation in the NAc of rodents. Mice $(\boldsymbol{A}, \boldsymbol{B})$ and rats $(\boldsymbol{C})$ were exposed to alcohol as described in Figure 1 , and the levels of $\mathrm{pSer}{ }^{916} \mathrm{GRF} 1$ as well as total GRF1 were determined by Western blot analysis. The level of GRF1 phosphorylation is expressed as the ratio of the phosphorylated protein to the total protein and presented as percentage of control. $\boldsymbol{B}, \mathrm{A}$ correlation between the level of H-Ras-GTP $\left(y\right.$-axis; Fig. 1A) and phosphor-Ser ${ }^{916}$-GRF1 $(x$-axis; $A)$ in the NAc of mice following systemic administration of saline (left) or alcohol (right). Correlation was analyzed by linear regression, the effect size ( $r^{2}$ value) was calculated, and the $p$ value was determined. Two-tailed unpaired $t$ test, ${ }^{* *} p<0.01 ; n=9$ per group $(\boldsymbol{A})$ and one-tailed unpaired $t$ test, ${ }^{*} p<0.05 ; n=4$ per group (B).

2.98, $p=0.01)$ compared with animals infected with the control viruses Ltv-NS and Ltv-SCR (Fig. 3B, C).

\section{H-Ras in the NAc contributes to alcohol-drinking behaviors}

Next, we set out to identify the behavioral consequences of alcohol-mediated H-Ras activation in the NAc of rodents. First, the NAc of mice were infected with Ltv-shH-Ras1 or Ltv-NS (Experiment 1) and with Ltv-shH-Ras2 or Ltv-SCR (Experiment 2 ), and the level of voluntary intake of a high alcohol solution $(20 \%)$ and water was measured. As shown in Figure 4, knockdown of H-Ras with Ltv-shH-Ras1 (Fig. 4Aa) or Ltv-shH-Ras2 (Fig. $4 \mathrm{Ba}$ ) resulted in a robust reduction of daily alcohol intake compared with mice infected with Ltv-NS [Experiment 1: Fig. $4 A a$; two-way ANOVA with repeated measures (RM), significant main effects of Ltv-shH-Ras1 infusion $\left(F_{(1,22)}=21.11, p<\right.$ $0.001)$, no significant effects of weeks $\left(F_{(1,22)}=3.25, p=0.085\right)$, and no interaction $\left.\left(F_{(1,22)}=0.51, p=0.48\right)\right]$ or Ltv-SCR [(Experiment 2: Fig. 4Ba; two-way ANOVA with RM, significant main effects of LtvshH-Ras2 infusion $\left(F_{(1,25)}=9.97, p=0.004\right)$ and weeks $\left(F_{(1,25)}=7.67, p<0.001\right)$, but no interaction $\left(F_{(1,25)}=\right.$ $0.04, p=0.84)]$. Subsequent analyses using the method of contrasts detected a significant difference in alcohol intake within week 1 and 2 between mice infused with Ltv-shH-Ras 1
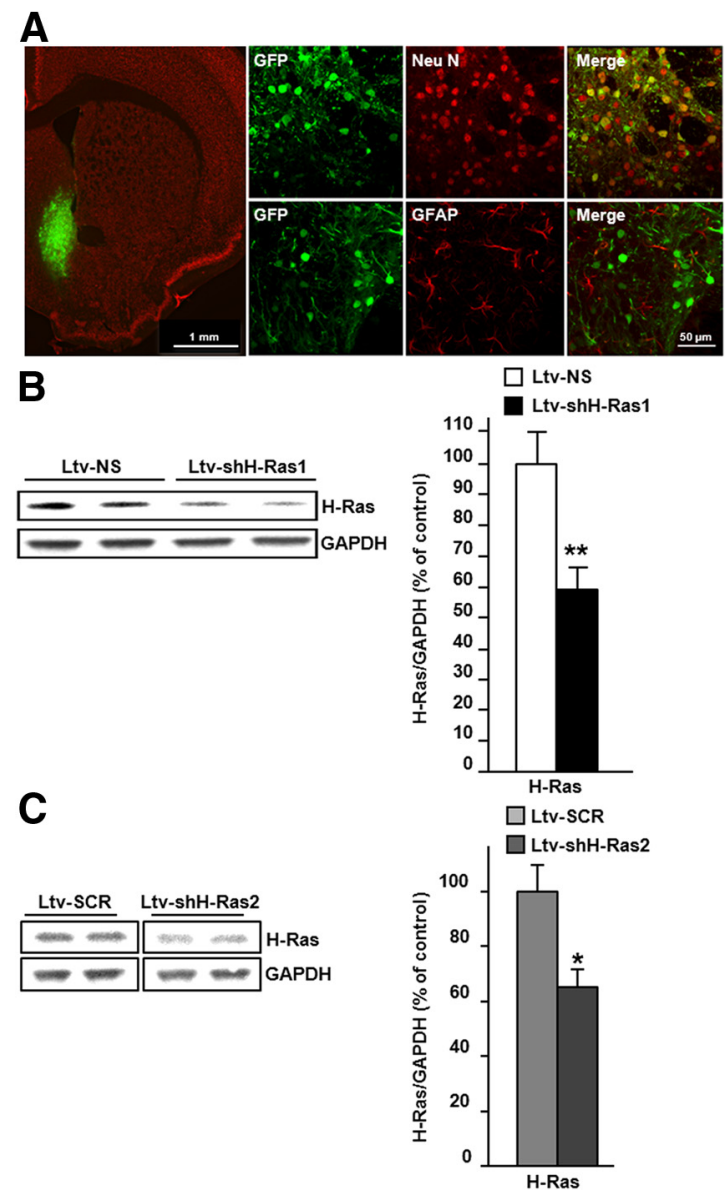

Figure 3. Infection of mice NAc with lentivirus expressing shRNA that targets $\mathrm{H}$-Ras produces a downregulation of the protein. Ltv-shH-Ras1 $(\boldsymbol{A}, \boldsymbol{B})$, Ltv-shH-Ras2 (C), Ltv-NS $(\boldsymbol{A}, \boldsymbol{B})$ or Ltv-SCR $(C)$ were bilaterally infused at a titer of $4 \times 10^{7} \mathrm{pg} / \mathrm{ml}$ into the NAc of mice. Analyses were conducted at the end of the behavioral experiments (8 weeks after the surgeries) described in the Figure 4 legend. $A$, Ltv-shH-Ras 1 infects NAc neurons. Left, Depicts the specificity of the site of infection, slices were costained with anti-GFP and anti-NeuN antibodies. Scale bar, $1 \mathrm{~mm}$. Right, Depicts costaining of GFP with NeuN (top) or GFAP (bottom). Scale bar, $50 \mu \mathrm{m} . \boldsymbol{B}$, C, Ltv-shH-Ras1 ( $\boldsymbol{B}$ ) or Ltv-shH-Ras2 ( $\boldsymbol{C}$ ) decreases the protein level of H-Ras in the NAc. The level of $\mathrm{H}$-Ras was determined by Western blot analysis using anti-H-Ras antibody (left, top), and GAPDH immunoreactivity was used as an internal loading control (left, bottom). Right, Histogram depicts the mean ratio of $\mathrm{H}-\mathrm{Ras} / \mathrm{GAPDH} \pm$ SEM and data are expressed as the percentage of control (Ltv-NS infected mice). Two-tailed unpaired $t$ test, ${ }^{*} p<0.05,{ }^{* *} p<0.01 ; n=7-8$ $(B), n=7(C)$ per group.

or Ltv-shH-Ras2 and their corresponding controls ( $p$ values $<0.001$ for Experiment 1and $p$ values $<0.05$ for Experiment 2). Importantly, H-Ras knockdown did not change water intake [Experiment 1: Fig. $4 A b$; two-way ANOVA with RM, no effects of Ltv-shH-Ras1 infusion $\left(F_{(1,22)}=1.60, p=0.22\right)$, a significant effects of weeks $\left(F_{(1,22)}=4.74, p=0.04\right)$, and no interaction $\left(F_{(1,22)}=0.22, p=0.64\right)$ and Experiment 2: $4 \mathrm{Bb}$; two-way ANOVA with RM, no effects of Ltv-shH-Ras2 infusion $\left(F_{(1,25)}=2.76, p=0.11\right)$, a significant effect of weeks $\left(F_{(1,22)}=\right.$ $6.29, p=0.19)$, and no interaction $\left.\left(F_{(1,22)}=0.01, p=0.94\right)\right]$. Subsequent analyses using the method of contrasts did not show a difference on water intake within week 1 and 2 between mice infused with Ltv-shH-Ras1 or Ltv-shH-Ras2 and their corresponding controls, but reduced the preference for alcohol versus water [Experiment 1: Fig. 4Ac; two-way ANOVA with RM, significant main effects of Ltv-shH-Ras1 infusion $\left(F_{(1,22)}=11.72\right.$, $p=0.002)$ and weeks $\left(F_{(1,22)}=10.26, p=0.004\right)$, but no interaction $\left(F_{(1,22)}=0.29, p=0.87\right)$ and Experiment 2: Figure $4 B c$; 
A
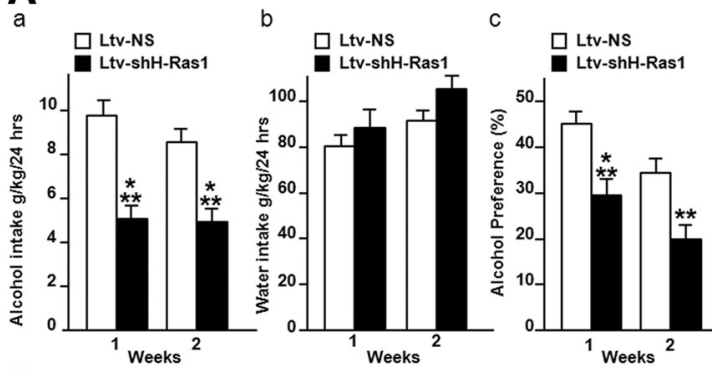

B

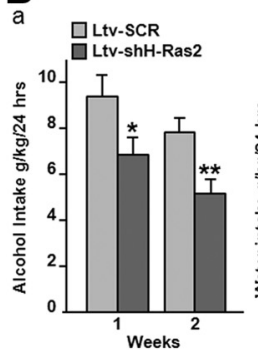

b $\quad$ Ltv-SCR
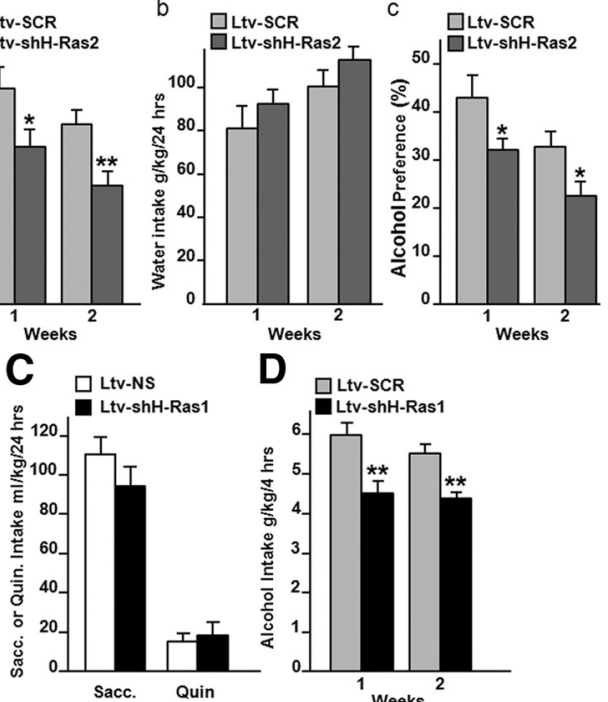

D $\mathrm{DLtv}-\mathrm{SCR}$

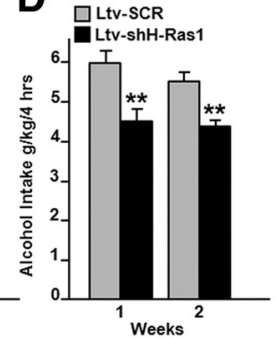

Figure 4. Downregulation of H-Ras expression in the NAc of mice reduces alcohol intake. $\boldsymbol{A}, \boldsymbol{B}$, Knockdown of $\mathrm{H}$-Ras in the NAc of mice reduces alcohol intake. Mice were infused with Ltv-shH-Ras1 $(\boldsymbol{A})$, Ltv-shH-Ras2 $(\boldsymbol{B})$, or the control viruses Ltv-NS $(\boldsymbol{A})$ or Ltv-SCR $(\boldsymbol{B})$ in the NAc. Four weeks later, animals were tested in a continuous-access $20 \%$ alcohol two-bottle choice drinking protocol. Mice were allowed access to two bottles, one containing a $20 \%$ alcohol solution (v/v) and one containing tap water for 2 weeks. $\mathbf{A a}, \mathbf{B a}$, Average of daily alcohol intake per week. $\boldsymbol{A} \boldsymbol{b}, \boldsymbol{B} \boldsymbol{b}$, Average of daily water intake per week. $A C, B C$, Average of daily alcohol preference per week. Alcohol preference was calculated as the percentage of alcohol solution consumed relative to total fluid intake (alcohol + water). C, Knockdown of H-Ras in the NAc of mice does not alter intake of saccharin or quinine. Saccharin or quinine intake was each provided for 3 successive days. D, Knockdown of $\mathrm{H}$-Ras in the NAc of mice attenuates binge drinking of alcohol. Mice were infused with Ltv-shH-Ras1 or Ltv-SCR into the NAc. Four weeks later, mice had access to a 20\% alcohol solution $(\mathrm{v} / \mathrm{v})$ for $4 \mathrm{~h}$ every other day for 2 weeks. Alcohol intake was measured at the end of each $4 \mathrm{~h}$ session, and presented as average of daily alcohol intake per week. Data are presented as mean $\pm \operatorname{SEM}(\boldsymbol{A}, \boldsymbol{B}, \boldsymbol{D})$ Newman-Keuls post hoc test and method of contrasts (C). Two-tailed unpaired $t$ test, ${ }^{*} p<0.05,{ }^{* *} p<0.01,{ }^{* * *} p<0.001 ; n=12$ per group $(\boldsymbol{A}, \boldsymbol{C}, \boldsymbol{D}), n=13-14$ per group $(\boldsymbol{B})$.

two-way ANOVA with RM, significant main effects of LtvshHRas2 infusion $\left(F_{(1,25)}=8.08, p=0.009\right)$ and weeks $\left(F_{(1,25)}=\right.$ 21.30, $p<0.001)$, but no interaction $\left.\left(F_{(1,25)}=0.14, p=0.71\right)\right]$. Subsequent analyses using the method of contrasts detected a significant difference in alcohol preference within week 1 and 2 between mice infused with Ltv-shH-Ras1 or Ltv-shH-Ras2 and their corresponding controls ( $p$ values $<0.01$ for Experiment 1 and $p$ values $<0.05$ for Experiment 2 ). Next, to verify that the reduction in alcohol intake and preference in response to $\mathrm{H}$-Ras knockdown was not due to nonspecific alterations in consummatory behaviors and/or taste palatability, the same animals used for Experiment 1 were tested for saccharin (sweet) or quinine (bitter) intake. As shown in Figure 4C, mice infected with Ltv-shH-Ras1
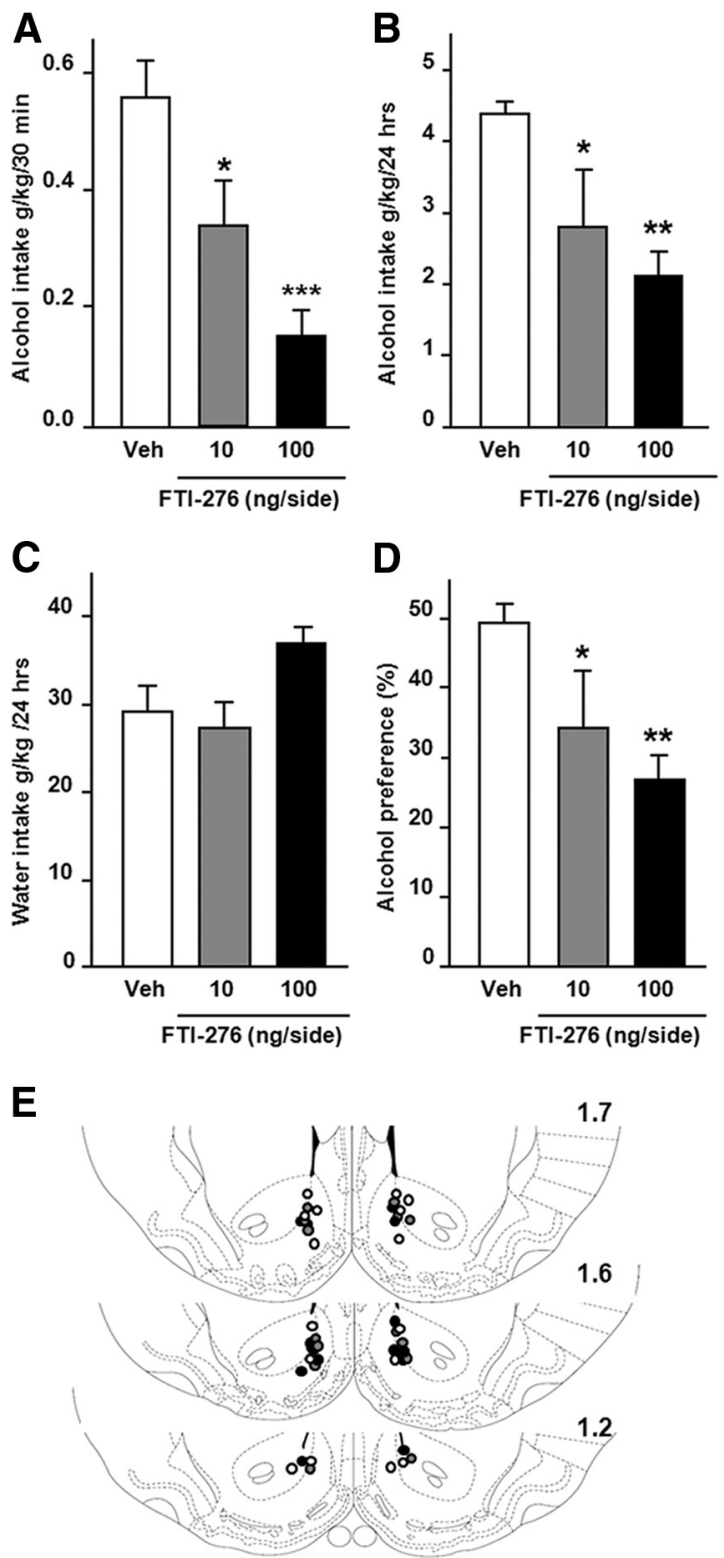

Figure 5. Inhibition of farnesyl transferase activity in the rat NAc reduces excessive drinking of alcohol. $\boldsymbol{A}-\boldsymbol{D}$, Intra-NAc infusion of FTI-276 reduces binge and sustained drinking of alcohol. Rats were trained to consume a $20 \%$ alcohol solution in the intermittent-access two-bottle choice drinking paradigm. Vehicle (Veh) or FTI-276 (10 or $100 \mathrm{ng} /$ side) was infused into the NAC $3 \mathrm{~h}$ before the beginning of the drinking session, and alcohol intake was measured after $30 \mathrm{~min}$ $(\boldsymbol{A})$ and $24 \mathrm{~h}(\boldsymbol{B})$. Water consumption was measured at the end of the $24 \mathrm{~h}$ session $(\boldsymbol{C})$, and alcohol preference $(\boldsymbol{D})$ was calculated as described in the legend of Figure 4. $\boldsymbol{E}$, Schematic drawings of coronal sections of the rat brain showing the placement of bilateral injection sites in the NAc. Histologically reconstructed sites of infusion localized in the NAc of rats that were included in the analysis of experiments. White circles refer to vehicle-treated group, gray circles refer to rats infused with FTI-276 (10 ng/side), and black circles refer to rats infused with FTI-276 (100 ng/side). Data are presented as mean \pm SEM. Newman-Keuls post hoc test, ${ }^{*} p<0.05$, ${ }^{* *} p<0.01,{ }^{* * *} p<0.001$ compared with vehicle; $n=7-8$ per group.

or Ltv-NS drank similar amounts of saccharin $\left(t_{(22)}=0.84, p=\right.$ $0.41)$ or quinine $\left(t_{(22)}=0.33, p=0.74\right)$ solutions. In addition, spontaneous locomotor activity was examined $3 \mathrm{~d}$ after the end of the saccharin- and quinine-drinking experiments, and no difference was observed between the groups (data not shown).

Furthermore, we found that H-Ras knockdown in the NAc significantly reduced limited access binge-like alcohol drinking in mice [Fig. 4D; two-way ANOVA with RM, main effects of 


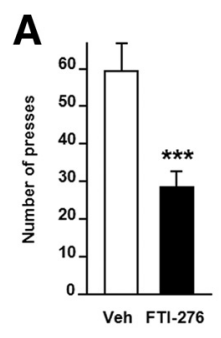

B
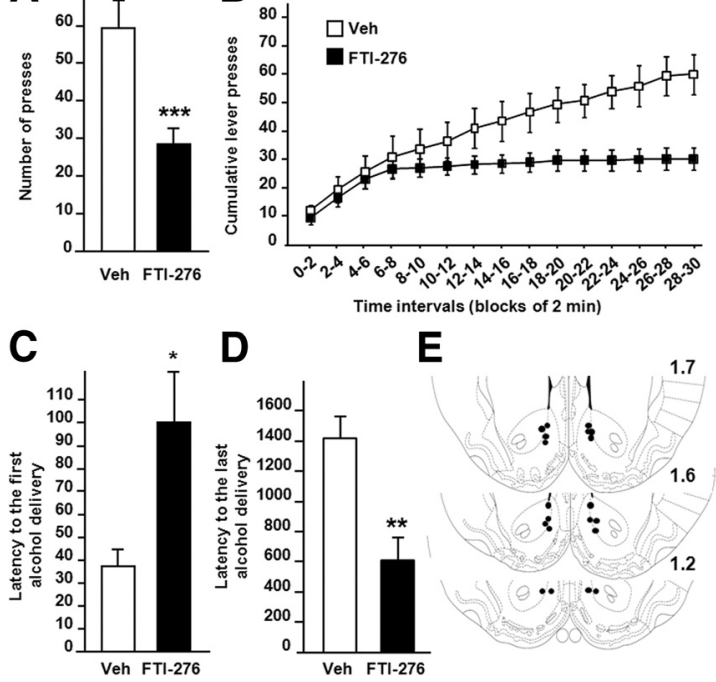

E

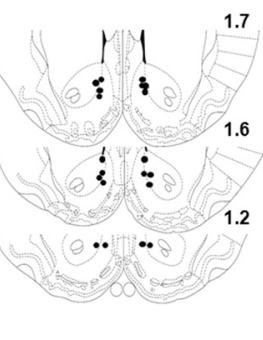

Figure 6. Inhibition of H-Ras activity in the NAc reduces operant self-administration of alcohol in rats. Rats with a history of high levels of alcohol consumption in an intermittent-access $20 \%$ alcohol two-bottle choice drinking paradigm were trained to orally self-administer a solution of $20 \%$ alcohol in an operant procedure on an FR3 schedule. Three hours before the beginning of 30 min session, FTl-276 (100 ng/side) was infused into the NAc of rats. $A$, Number of active lever presses during the 30 min operant alcohol self-administration session. $\boldsymbol{B}$, Cumulative mean presses in bins of $2 \mathrm{~min}$, indicative of the rate of presses for alcohol during the session. C, Latency to the first alcohol delivery ( $0.1 \mathrm{ml}$ of $20 \%$ alcohol/delivery) obtained during the 30 min session. $\boldsymbol{D}$, Latency to the last alcohol delivery. $\boldsymbol{E}$, Schematic drawings of coronal sections of the rat brain showing the placement of bilateral injection sites in the NAc. Histologically reconstructed sites of infusion localized in the NAc of rats that were included in the analysis of experiments. Data are represented as mean \pm SEM. Newman-Keuls post hoc test, ${ }^{*} p<$ $0.05,{ }^{* *} p<0.01{ }^{* * *} p<0.001 ; n=10$ per group.

Ltv-shH-Ras1 infusion $\left(F_{(1,22)}=23.92, p<0.001\right)$, no effect of weeks $\left(F_{(1,22)}=2.23, p=0.15\right)$, and no interaction $\left(F_{(1,22)}=\right.$ $0.53, p=0.47)]$. Subsequent analysis using the method of contrasts detected a significant difference on binge alcohol intake between mice infused with Ltv-NS or Ltv- shH-Ras1 within week 1 and 2 ( $p$ values $<0.01)$.

Next, we examined whether pharmacological inhibition of $\mathrm{H}$-Ras activity in the NAc reduces binge drinking of alcohol. Farnesyl transferase is required for anchoring and signaling of p21Ras (Zhang and Casey, 1996; Ahearn et al., 2012). Therefore, to inhibit H-Ras activity we used the farnesyl transferase inhibitor, FTI-276, a highly potent and selective antagonist of p21Ras proteins (Sebti and Hamilton, 2000). Rats were infused with vehicle or FTI-276 into the NAc $3 \mathrm{~h}$ before the beginning of the drinking session and alcohol intake was measured at the end of the $30 \mathrm{~min}$ session. The levels of alcohol intake prevehicle (4.9 \pm $0.4 \mathrm{~g} / \mathrm{kg}$ ) and postinfusion of vehicle (10\% DMSO) $(4.4 \mathrm{~g} / \mathrm{kg} \pm$ $0.2 \mathrm{~g} / \mathrm{kg})$ were not significantly different $\left(t_{(14)}=1.16, p=0.26\right)$. Intra-NAc infusion of FTI-276 dose dependently decreased binge $(30 \mathrm{~min})$ intake of alcohol (Fig. $5 \mathrm{~A}$; one-way ANOVA; $F_{(2,20)}=$ $12.32, p<0.001)$ and excessive consumption of alcohol over the $24 \mathrm{~h}$ session (Fig. $5 B$; one-way ANOVA; $F_{(2,20)}=6.38, p=0.007$ ). Water consumption was similar in vehicle- and FTI-276treated rats (Fig. $5 C$ ), and the preference for alcohol was reduced (Fig. 5D; one-way ANOVA; $F_{(2,20)}=5.76, p=0.011$ ). Together, these results strongly imply that $\mathrm{H}$-Ras in the NAc plays an essential role in mechanisms underlying excessive drinking of alcohol.

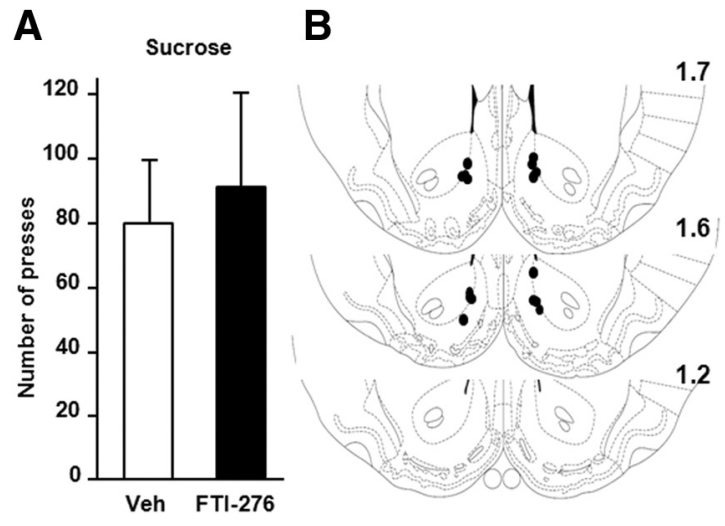

Figure 7. Intra-NAc infusion of FTI-276 does not alter self-administration of sucrose. $\boldsymbol{A}$, Rats were trained to self-administer a solution of $1.5 \%$ sucrose in an operant procedure. Three hours before the beginning of the 30 min session, rats were infused in the NAc with FTI-276 (100 $\mathrm{ng} / \mathrm{side}$ ) or vehicle (Veh) and the number of presses on the sucrose lever during the $30 \mathrm{~min}$ operant self-administration session was recorded. $\boldsymbol{B}$, Schematic drawings of coronal sections of the rat brain showing the placement of bilateral injection sites in the NAc. Histologically reconstructed sites of infusion localized in the NAc of rats were included in the analysis of experiments. Data are presented as mean \pm SEM. $n=8$ per group.

\section{Inhibition of farnesyl transferase activity in the NAc of rats attenuates operant self-administration of alcohol but not sucrose}

Operant self-administration was used next to assess the contribution of H-Ras in the NAc to the motivation of rats to lever press for alcohol. As shown in Figure 6, $A$ and $B$, infusion of FTI-276 into the NAc of rats significantly reduced operant responding for a high alcohol solution $(20 \%)$ (one-way ANOVA with RM; $F_{(1,9)}=32.51$, $p<0.001$ ). In addition, FTI-276 treatment displayed an early termination of the drinking episode compared with vehicle-treated rats [Fig. 6B; two-way ANOVA with RM revealed significant main effects of time $\left(F_{(14,126)}=33.00, p<0.001\right)$, treatment $\left(F_{(1,126)}=\right.$ 9.53, $p=0.013)$, and time $\times$ treatment interaction $\left(F_{(14,126)}=\right.$ 11.32, $p<0.001)$.] Rats treated with FTI-276 also displayed a significant increase in the latency to obtain the first reward (Fig. $\left.6 C ; F_{(1,9)}=5.34, p=0.046\right)$ and a decrease in the latency to obtain the last reward (Fig. $6 D ; F_{(1,9)}=13.41, p=0.005$ ). Together, these results suggest that H-Ras in the NAc is an important contributor to mechanisms that underlie the motivation to self-administer excessive amounts of alcohol.

We also measured lever-press responding for a natural rewarding substance, sucrose, in response to an intra-NAc infusion of the FTI-276, to determine whether the reduction of alcohol self-administration is due to a general alteration in rewardmotivated behaviors or attenuation of locomotor activity. To do so, rats were trained to self-administer a sucrose solution, and $3 \mathrm{~h}$ before the testing session, FTI-276 or vehicle was infused into the NAc. As shown in Figure 7, intra-NAc infusion of FTI-276 did not alter lever press responding for sucrose $\left(F_{(1,7)}=0.41, p=\right.$ $0.55)$. In addition, no significant effect on the distribution of inter-response intervals was observed between the groups (data not shown). Therefore, alterations in general reward-motivated behaviors or locomotor activity cannot account for the inhibitory actions of FTI-276 on self-administration of alcohol.

Inhibition of farnesyl transferase activity in the NAc of rats attenuates alcohol seeking

Finally, to test whether H-Ras drives alcohol-seeking behavior, FTI-276 was infused into the NAc of rats that underwent an extinction session in which rats were able to respond but did not 
A

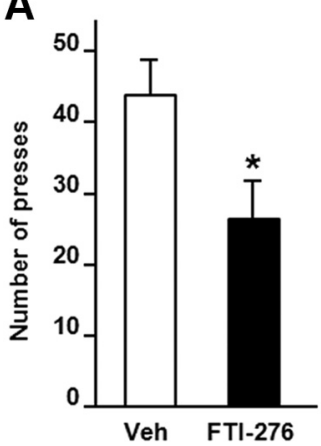

C

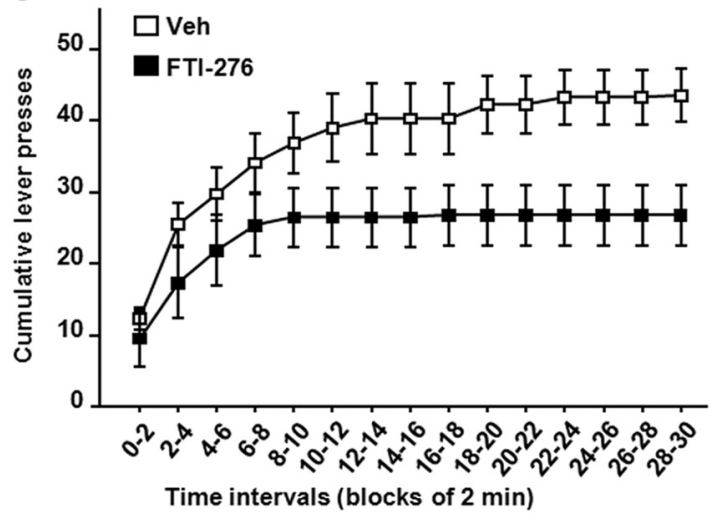

Figure 8. Inhibition of H-Ras activity reduces alcohol-seeking behavior in rats. Rats with a history of high levels of alcohol consumption in an intermittent-access $20 \%$ alcohol two-bottle choice drinking paradigm were trained to orally self-administer a solution of $20 \%$ alcohol in an operant procedure on an FR3 schedule. Three hours before the beginning of a 30 min extinction session (alcohol was not delivered), FTI-276 (100 ng/side) or vehicle (Veh) was infused into the NAc. $\boldsymbol{A}$, Graph of the number of active lever presses during the 30 min session. $\boldsymbol{B}$, Shows latency to the third press. $\boldsymbol{C}$, Cumulative mean presses in bins of $2 \mathrm{~min}$; data are presented as mean \pm SEM. Newman-Keuls post hoc test, ${ }^{*} p<0.05 ; n=9$ per group.

receive an alcohol reward. As shown in Figure 8, infusion of FTI-276 into the NAc significantly decreased the number of presses on the alcohol-paired lever (Fig. 8A; one-way ANOVA with $\left.\mathrm{RM} ; F_{(1,8)}=6.92, p=0.03\right)$, and increased the latency to the third press, which is the response followed by reward under FR3 schedule (Fig. $8 B$; one-way ANOVA with RM; $F_{(1,8)}=5.37, p=$ 0.049 ). We also observed that the pattern of lever presses during the extinction session [Fig. 8C; two-way ANOVA with RM, main effects of time $\left(F_{(14,112)}=42.05, p<0.001\right)$, treatment $\left(F_{(1,112)}=\right.$ $9.53, p=0.07)$, and treatment $\times$ time interaction $\left(F_{(14,112)}=11.32\right.$, $p<0.001)$ ] was similar to the pattern during self-administration in the presence of the drug (Fig. 6B). Together, these results suggest that intra-NAc infusion of FTI-276 reduces the motivation of rats to seek alcohol.

\section{Discussion}

Here, we show that systemic administration of alcohol as well as alcohol self-administration leads to the activation of the small $\mathrm{G}$ protein, $\mathrm{H}$-Ras, in the NAc, a brain region heavily implicated in reward-seeking behaviors (Hyman et al., 2006). We further show that downregulation of $\mathrm{H}$-Ras protein levels or pharmacological inhibition of its activity in the NAc significantly reduces excessive alcohol drinking and seeking in rodents.

We found that H-Ras is activated in the NAc in response to both acute and prolonged alcohol exposure. It is very plausible that alcohol intake initiates the stimulation of $\mathrm{H}$-Ras and that the continuous/chronic activation of this cascade by alcohol is nec- essary for the development and maintenance of alcohol-related behaviors. Thus, H-Ras contributes to both the onset as well as the maintenance of maladaptive signaling cascades that mediate alcohol-drinking behaviors. The fact that both acute and chronic drug exposures activate a protein with enzymatic activity in vivo is not unique to $\mathrm{H}$-Ras. For example, AKT and mammalian target of rapamycin in complex 1 (mTORC1) kinases are activated in the NAc in response to acute and prolonged intake of alcohol (Neasta et al., 2010, 2011), and both stimulants and opiates acutely and chronically activate the transcription factor, cAMP response binding-element, in the NAc which, in turn, promotes drug-related behaviors (Robison and Nestler, 2011).

The mechanism of $\mathrm{H}$-Ras activation in response to alcohol exposure has yet to be elucidated. Activation of growth factors or G-protein-coupled receptors as well as calcium leads to the activation of p21Ras proteins (Cox and Der, 2010). We provide evidence suggesting that GRF1 (a GDP to GTP exchange factor) is, at least in part, the upstream mediator of $\mathrm{H}$-Ras activation in these paradigms. GRF1 is reported to be specifically activated by lysophosphatidic acid, the neurotrophic factor receptors, Trk, cannabinoid receptors, and calcium as well as cAMP/PKA (Fernández-Medarde and Santos, 2011). Our results link the activation of GRF1 by alcohol to the cAMP/PKA pathway. Specifically, alcohol exposure resulted in increased phosphorylation of GRF1 on a PKA site (serine 916), a post-translational modification that enhances the intrinsic GDP to GTP exchange activity of GRF1 (Mattingly, 1999; Yang et al., 2003). Although the increase in GRF1 activity can influence the function of other members of the p21Ras family, several studies suggest that GRF1 is the specific exchange factor for H-Ras but not N-Ras or K-Ras (FernándezMedarde and Santos, 2011). Activation of dopamine D1/D5 receptors, which are coupled to cAMP/PKA signaling, are positively associated with GRF1 function in the striatum (Fasano et al., 2009). Both systemic and voluntary administration of alcohol results in an increase in dopamine levels in the NAc of rodents (Gonzales et al., 2004). Therefore, it is plausible that alcoholmediated release of dopamine will result in the phosphorylation of GRF1, leading to the activation of H-Ras.

We show that infection of mouse NAc neurons with lentiviruses expressing specific siRNA sequences that target H-Ras reduced excessive alcohol intake, whereas lentiviruses expressing two controls (a nonspecific RNA sequence or a scrambled H-Ras siRNA sequence) did not. These results strongly suggest that the alteration in alcohol intake by the knockdown of $\mathrm{H}$-Ras in the NAc is not due to off target effects. We also report that the inhibition of farnesyl transferase activity attenuated binge drinking as well as seeking in the absence of alcohol reward. Although we cannot rule out the possibility that other farnesylated proteins contribute to mechanisms that underlie excessive alcohol drinking behaviors, the robust activation of $\mathrm{H}$-Ras in response to alcohol and the attenuation of behaviors associated with alcohol exposure after the knockdown of the small GTPase strongly imply that H-Ras is a main target of alcohol in the NAc.

The downstream target of $\mathrm{H}$-Ras activation by alcohol is likely to be the PI3K/AKT. PI3K and AKT are activated in response to the activation of $\mathrm{p} 21$ Ras. The PI3K/AKT pathway is activated in the NAc in response to alcohol, and inhibition of these kinases attenuates alcohol intake (Cozzoli et al., 2009; Neasta et al., 2011). Furthermore, a downstream target of AKT is the mTORC1, a serine/threonine kinase that plays an essential role in plasticity mechanisms and learning and memory via the translation of a subset of synaptic proteins in dendrites (Hoeffer and Klann, 2010; Wang et al., 2010). We recently obtained data that link 
mTORC1 in the NAc to neuroadaptations that underlie alcohol consumption and reward (Neasta et al., 2010). Specifically, we observed that systemic administration of a nonhypnotic dose of alcohol, as well as alcohol intake result in the phosphorylation of the mTORC1 substrates, the eukaryotic translation initiation factor-4E binding protein, and S6 kinase, in the NAc of rodents (Neasta et al., 2010). We further showed that the activation of mTORC1 leads to the increase in protein levels of specific synaptic proteins and that inhibition of MTORC1 pathway decreases alcohol-drinking and alcohol-seeking behaviors (Neasta et al., 2010). Together, these results raise the possibility that H-Ras in the NAc is positioned at a focal cross point that enables the activation of mTORC1 which, in turn, produces molecular adaptations that underlie the development and/or expression of excessive alcohol-drinking and alcohol-seeking behaviors.

The possible role of $\mathrm{H}$-Ras in the NAc in mechanisms that underlie alcohol intake correlates with a genomic study, which was aimed to characterize genes implicated in the susceptibility to develop alcohol abuse disorders. Specifically, Mulligan et al. (2006) reported that the H-Ras transcript is significantly increased in the brain of selected lines of mice that consume high amounts of alcohol. In addition, a genetic variation in PI3K, a main downstream target of $\mathrm{H}$-Ras protein, has been linked to patterns of risky alcohol consumption in human male adolescents (Desrivières et al., 2008). This raises the possibility that $\mathrm{H}$-Ras signaling may play an important role in the transition from controlled to excessive compulsive alcohol intake in humans. Importantly, our findings put forward the possibility that targeting $\mathrm{H}$-Ras activity could be a valuable strategy for the treatment of alcohol use and abuse disorders.

\section{References}

Ahearn IM, Haigis K, Bar-Sagi D, Philips MR (2012) Regulating the regulator: post-translational modification of RAS. Nat Rev Mol Cell Biol 13:39-51. Medline

Alpár A, Gärtner U, Seeger G, Härtig W, Brauer K, Arendt T (2004) Constitutive expression of $\mathrm{p} 21 \mathrm{H}$-ras(Val12) in pyramidal neurons results in reorganization of mouse neocortical afferents. J Neurobiol 60:263-274. CrossRef Medline

Baouz S, Jacquet E, Accorsi K, Hountondji C, Balestrini M, Zippel R, Sturani E, Parmeggiani A (2001) Sites of phosphorylation by protein kinase A in $\mathrm{CDC} 25 \mathrm{Mm} / \mathrm{GRF} 1$, a guanine nucleotide exchange factor for Ras. J Biol Chem 276:1742-1749. Medline

Barak S, Carnicella S, Yowell QV, Ron D (2011) Glial cell line-derived neurotrophic factor reverses alcohol-induced allostasis of the mesolimbic dopaminergic system: implications for alcohol reward and seeking. J Neurosci 31:9885-9894. CrossRef Medline

Bos JL, Rehmann H, Wittinghofer A (2007) GEFs and GAPs: critical elements in the control of small G proteins. Cell 129:865-877. CrossRef Medline

Brambilla R, Gnesutta N, Minichiello L, White G, Roylance AJ, Herron CE, Ramsey M, Wolfer DP, Cestari V, Rossi-Arnaud C, Grant SG, Chapman PF, Lipp HP, Sturani E, Klein R (1997) A role for the Ras signalling pathway in synaptic transmission and long-term memory. Nature 390: 281-286. CrossRef Medline

Carnicella S, Amamoto R, Ron D (2009) Excessive alcohol consumption is blocked by glial cell line-derived neurotrophic factor. Alcohol 43:35-43. CrossRef Medline

Castellano E, Downward J (2011) RAS interaction with PI3K: more than just another effector pathway. Genes Cancer 2:261-274. CrossRef Medline

Costa RM, Federov NB, Kogan JH, Murphy GG, Stern J, Ohno M, Kucherlapati R, Jacks T, Silva AJ (2002) Mechanism for the learning deficits in a mouse model of neurofibromatosis type 1. Nature 415:526-530. CrossRef Medline

Cox AD, Der CJ (2010) Ras history: the saga continues. Small GTPases 1:227. CrossRef Medline

Cozzoli DK, Goulding SP, Zhang PW, Xiao B, Hu JH, Ary AW, Obara I, Rahn
A, Abou-Ziab H, Tyrrel B, Marini C, Yoneyama N, Metten P, Snelling C, Dehoff MH, Crabbe JC, Finn DA, Klugmann M, Worley PF, Szumlinski KK (2009) Binge drinking upregulates accumbens mGluR5-Homer2PI3K signaling: functional implications for alcoholism. J Neurosci 29: 8655-8668. CrossRef Medline

Desrivières S, Krause K, Dyer A, Frank J, Blomeyer D, Lathrop M, Mann K, Banaschewski T, Laucht M, Schumann G (2008) Nucleotide sequence variation within the PI3K p85 alpha gene associates with alcohol risk drinking behaviour in adolescents. PLoS One 3:e1769. CrossRef Medline

Fasano S, D’Antoni A, Orban PC, Valjent E, Putignano E, Vara H, Pizzorusso T, Giustetto M, Yoon B, Soloway P, Maldonado R, Caboche J, Brambilla R (2009) Ras-guanine nucleotide-releasing factor 1 (Ras-GRF1) controls activation of extracellular signal-regulated kinase (ERK) signaling in the striatum and long-term behavioral responses to cocaine. Biol Psychiatry 66:758-768. CrossRef Medline

Feig LA (2011) Regulation of neuronal function by Ras-GRF exchange factors. Genes Cancer 2:306-319. CrossRef Medline

Fernández-Medarde A, Santos E (2011) The RasGrf family of mammalian guanine nucleotide exchange factors. Biochim Biophys Acta 1815:170 188. Medline

Gärtner U, Alpár A, Reimann F, Seeger G, Heumann R, Arendt T (2004) Constitutive Ras activity induces hippocampal hypertrophy and remodeling of pyramidal neurons in synRas mice. J Neurosci Res 77:630-641. CrossRef Medline

Gonzales RA, Job MO, Doyon WM (2004) The role of mesolimbic dopamine in the development and maintenance of ethanol reinforcement. Pharmacol Ther 103:121-146. CrossRef Medline

Hoeffer CA, Klann E (2010) mTOR signaling: at the crossroads of plasticity, memory and disease. Trends Neurosci 33:67-75. CrossRef Medline

Hyman SE, Malenka RC, Nestler EJ (2006) Neural mechanisms of addiction: the role of reward-related learning and memory. Annu Rev Neurosci 29:565-598. CrossRef Medline

Kaneko M, Cheetham CE, Lee YS, Silva AJ, Stryker MP, Fox K (2010) Constitutively active $\mathrm{H}$-ras accelerates multiple forms of plasticity in developing visual cortex. Proc Natl Acad Sci U S A 107:19026-19031. CrossRef Medline

Kim JH, Lee HK, Takamiya K, Huganir RL (2003) The role of synaptic GTPase-activating protein in neuronal development and synaptic plasticity. J Neurosci 23:1119-1124. Medline

Koob GF (2003) Alcoholism: allostasis and beyond. Alcohol Clin Exp Res 27:232-243. CrossRef Medline

Koob GF, Volkow ND (2010) Neurocircuitry of addiction. Neuropsychopharmacology 35:217-238. CrossRef Medline

Kushner SA, Elgersma Y, Murphy GG, Jaarsma D, van Woerden GM, Hoijati MR, Cui Y, LeBoutillier JC, Marrone DF, Choi ES, De Zeeuw CI, Petit TL, Pozzo-Miller L, Silva AJ (2005) Modulation of presynaptic plasticity and learning by the $\mathrm{H}$-ras/extracellular signal-regulated kinase/synapsin I signaling pathway. J Neurosci 25:9721-9734. CrossRef Medline

Lasek AW, Janak PH, He L, Whistler JL, Heberlein U (2007) Downregulation of mu opioid receptor by RNA interference in the ventral tegmental area reduces ethanol consumption in mice. Genes Brain Behav 6:728 735. CrossRef Medline

Leon J, Guerrero I, Pellicer A (1987) Differential expression of the ras gene family in mice. Mol Cell Biol 7:1535-1540. Medline

Mailliard WS, Diamond I (2004) Recent advances in the neurobiology of alcoholism: the role of adenosine. Pharmacol Ther 101:39-46. CrossRef Medline

Manabe T, Aiba A, Yamada A, Ichise T, Sakagami H, Kondo H, Katsuki M (2000) Regulation of long-term potentiation by H-Ras through NMDA receptor phosphorylation. J Neurosci 20:2504-2511. Medline

Mattingly RR (1999) Phosphorylation of serine 916 of Ras-GRF1 contributes to the activation of exchange factor activity by muscarinic receptors. J Biol Chem 274:37379-37384. CrossRef Medline

McGough NN, He DY, Logrip ML, Jeanblanc J, Phamluong K, Luong K, Kharazia V, Janak PH, Ron D (2004) RACK1 and brain-derived neurotrophic factor: a homeostatic pathway that regulates alcohol addiction. J Neurosci 24:10542-10552. CrossRef Medline

Moodie SA, Willumsen BM, Weber MJ, Wolfman A (1993) Complexes of Ras.GTP with Raf- 1 and mitogen-activated protein kinase kinase. Science 260:1658-1661. CrossRef Medline

Mor A, Keren G, Kloog Y, George J (2008) N-Ras or K-Ras inhibition in- 
creases the number and enhances the function of Foxp3 regulatory T cells. Eur J Immunol 38:1493-1502. CrossRef Medline

Mulligan MK, Ponomarev I, Hitzemann RJ, Belknap JK, Tabakoff B, Harris RA, Crabbe JC, Blednov YA, Grahame NJ, Phillips TJ, Finn DA, Hoffman PL, Iyer VR, Koob GF, Bergeson SE (2006) Toward understanding the genetics of alcohol drinking through transcriptome meta-analysis. Proc Natl Acad Sci U S A 103:6368-6373. CrossRef Medline

Neasta J, Ben Hamida S, Yowell Q, Carnicella S, Ron D (2010) Role for mammalian target of rapamycin complex 1 signaling in neuroadaptations underlying alcohol-related disorders. Proc Natl Acad Sci U S A 107: 20093-20098. CrossRef Medline

Neasta J, Ben Hamida S, Yowell QV, Carnicella S, Ron D (2011) AKT signaling pathway in the nucleus accumbens mediates excessive alcohol drinking behaviors. Biol Psychiatry 70:575-582. CrossRef Medline

Orban PC, Chapman PF, Brambilla R (1999) Is the Ras-MAPK signalling pathway necessary for long-term memory formation? Trends Neurosci 22:38-44. CrossRef Medline

Robison AJ, Nestler EJ (2011) Transcriptional and epigenetic mechanisms of addiction. Nat Rev Neurosci 12:623-637. CrossRef Medline

Ron D, Messing RO (2013) Signaling pathways mediating alcohol effects. Curr Top Behav Neurosci 13:87-126. CrossRef Medline

Rubinson DA, Dillon CP, Kwiatkowski AV, Sievers C, Yang L, Kopinja J, Rooney DL, Zhang M, Ihrig MM, McManus MT, Gertler FB, Scott ML, Van Parijs L (2003) A lentivirus-based system to functionally silence genes in primary mammalian cells, stem cells and transgenic mice by RNA interference. Nat Genet 33:401-406. CrossRef Medline

Russo SJ, Dietz DM, Dumitriu D, Morrison JH, Malenka RC, Nestler EJ (2010) The addicted synapse: mechanisms of synaptic and structural plasticity in nucleus accumbens. Trends Neurosci 33:267-276. CrossRef Medline

Sebti SM, Hamilton AD (2000) Farnesyltransferase and geranylgeranyl- transferase I inhibitors and cancer therapy: lessons from mechanism and bench-to-bedside translational studies. Oncogene 19:6584-6593. CrossRef Medline

Simms JA, Steensland P, Medina B, Abernathy KE, Chandler LJ, Wise R, Bartlett SE (2008) Intermittent access to $20 \%$ ethanol induces high ethanol consumption in Long-Evans and Wistar rats. Alcohol Clin Exp Res 32:1816-1823. CrossRef Medline

Sprow GM, Thiele TE (2012) The neurobiology of binge-like ethanol drinking: evidence from rodent models. Physiol Behav 106:325-331. CrossRef Medline

Takai Y, Sasaki T, Matozaki T (2001) Small GTP-binding proteins. Physiol Rev 81:153-208. Medline

Thornton C, Yaka R, Dinh S, Ron D (2003) H-Ras modulates N-methyl-Daspartate receptor function via inhibition of Src tyrosine kinase activity. J Biol Chem 278:23823-23829. CrossRef Medline

Vengeliene V, Bilbao A, Molander A, Spanagel R (2008) Neuropharmacology of alcohol addiction. Br J Pharmacol 154:299-315. Medline

Wang DO, Martin KC, Zukin RS (2010) Spatially restricting gene expression by local translation at synapses. Trends Neurosci 33:173-182. CrossRef Medline

Yang H, Cooley D, Legakis JE, Ge Q, Andrade R, Mattingly RR (2003) Phosphorylation of the Ras-GRF1 exchange factor at Ser916/898 reveals activation of Ras signaling in the cerebral cortex. J Biol Chem 278: 13278-13285. CrossRef Medline

Ye X, Carew TJ (2010) Small G protein signaling in neuronal plasticity and memory formation: the specific role of ras family proteins. Neuron 68 : 340-361. CrossRef Medline

Zhang FL, Casey PJ (1996) Protein prenylation: molecular mechanisms and functional consequences. Annu Rev Biochem 65:241-269. CrossRef Medline 